TOMASZ StOLARCZYK

Biblioteka Uniwersytetu Łódzkiego

\title{
HISTORIA W BIBLIOLOGII. ROLA BADAŃ HISTORYCZNYCH W ODTWARZANIU DZIEJÓW BIBLIOTEK I KSIĘGOZBIORÓW
}

Barbara Bieńkowska w swoim artykule poświęconym badaniom księgozbiorów historycznych napisała, że

księgozbiory historyczne stanowią ważne i wielostronne [...] źródło wiedzy o przeszłości. Mogą one powiedzieć bardzo wiele o minionych czasach, o ludziach, rzeczach, zjawiskach i związkach pod warunkiem, że będą analizowane fachowo, $\mathrm{z}$ wykorzystaniem wszystkich dostępnych współcześnie metod i środków ${ }^{1}$.

Dla historyka książka to nośnik i narzędzie kultury w dziejach. Z kolei dla bibliologa książka i biblioteka są również faktem, procesem historycznym. „Książka [...] podlega takim samym aktom poznawczym jak wydarzenia o charakterze politycznym, społecznym, gospodarczym czy kulturowym"2.

Z kolei w ujęciu funkcjonalnym książka to nie tylko historyczny i społeczny fakt, ale i nieustanny proces komunikacji międzyludzkiej i społecznej, jako rzeczywistej i potencjalnej realizacji ról książki³. „Bada się zatem warunki i efekty jej działania: zagadnienia wytwarzania, rozpowszechniania

${ }^{1}$ B. Bieńkowska, Kilka uwag i propozycji w sprawie badań księgozbiorów historycznych, „Studia o Książce” (dalej: „SK”) 1986, t. 16, s. 3.

2 P. Dymmel, Nauki pomocnicze bibliologii (zarys problematyki), „Roczniki Biblioteczne” 1984, R. 28, s. 283; M. Juda, Bibliologia historyczna w systemie nauk pomocniczych historii [w:] Nauki pomocnicze historii. Teoria, metody badań, dydaktyka, pod red. A. Jaworskiej, R. Jopa, Warszawa 2013, s. 14.

3 J. Gwioździk, Historyczne kolekcje klasztorne. Zarys problematyki badań [w:] Bibliologia. Problemy badawcze nauk humanistycznych, pod red. D. Kuźminy, Warszawa 2007, s. 168. 
i użytkowania oraz społeczne funkcje i związki tekstu (bibliologia jest wówczas pojmowana jako nauka o komunikacji piśmienniczej)"4.

Księgozbiory historyczne w zależności od swych walorów i charakteru wymagają odmiennego postępowania naukowego: dokładnej analizy wszystkich elementów z rozmaitym stopniem precyzji aż do opracowań monograficznych włącznie, albo oceny globalnej, gdy kolekcja reprezentuje wartość historyczną jako całość, niezależnie od znaczenia poszczególnych jej obiektów ${ }^{5}$. „Badania księgozbiorów ujawniają coraz więcej możliwości poznawczych, coraz szersze też mają zastosowanie, zwłaszcza wobec upowszechniania się semiotycznej metodologii interpretacji źródeł historycznych"6.

Według Marii Judy „[...] badania nad dawną książką muszą być zintegrowane z ogólnymi badaniami historycznymi, przede wszystkim na etapie heurystyki i krytyki źródeł"7. Historyczne księgoznawstwo (bibliologia historyczna) jest „składnikiem nauk historycznych” i musi być oparte na solidnej podstawie źródłowej. „Nie może abstrahować od reguł uprawiania studiów historycznych, musi posiadać odpowiednie instrumentarium badawcze właściwe dyscyplinom historycznym. Toteż w zależności od konkretnych potrzeb badawczych historyk (kultury) książki sięgać musi do historii kultury materialnej i do historii kultury duchowej, do historii lite-

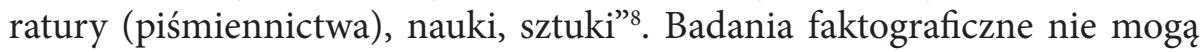
obejść się bez warsztatu i metod nauk pomocniczych historii, zwłaszcza te dotyczące książki dawnej, rękopiśmiennej i drukowanej ${ }^{9}$.

Według Alfreda Świerka, każdy, kto przystępuje do opracowania dziejów biblioteki, musi zdawać sobie sprawę, że "te same motory, które poruszają bieg dziejów kultury intelektualnej, leżą również u źródeł rozwoju bibliotek"10. Zdaniem tego badacza najważniejsza w całej problematyce jest również kwestia treści księgozbioru, natomiast takie zagadnienia jak jego organizacja, sposób zarządzania i zewnętrzne jego dzieje schodzą na dalszy plan. Historię bibliotek należy zatem rozpatrywać w jak najściślejszym powiązaniu z ogólnymi dziejami kultury umysłowej danej epoki ${ }^{11}$.

${ }^{4}$ Tamże, s. 168.

5 B. Bieńkowska, Kilka uwag..., s. 3.

6 Tamże, s. 6.

${ }^{7}$ M. Juda, Bibliologia historyczna..., s. 14.

${ }^{8}$ K. Migoń, Bibliologia wśród innych nauk. Koncepcje, realizacje, perspektywy [w:] Bibliologia. Problemy badawcze, s. 21.

9 Tamże, s. 21; M. Juda, Bibliologia historyczna..., s. 19.

${ }^{10}$ A. Świerk, Średniowieczna biblioteka klasztoru Kanoników Regularnych św. Augustyna w Żaganiu, Wrocław 1965, s. 6.

11 Tamże, s. 6. 
Dzieje bibliotek są jedną z najważniejszych dziedzin bibliologii historycznej. Niekiedy trzeba połączyć je z historią bibliofilstwa, które kieruje uwagę na oprawę, ekslibris i superekslibris ${ }^{12}$.

Dla opracowania całości materiału dotyczącego historycznych księgozbiorów i bibliotek najbardziej przydatna jest metoda, którą A. Świerk nazwał historyczno-genetyczną. Polega ona na szczegółowej analizie treści księgozbioru, „poprzez którą należy dojść do ogólnych wniosków o recepcji współczesnych prądów i kierunków umysłowych w danym konkretnym środowisku właścicieli i użytkowników biblioteki. Jest to droga indukcji i syntezy"13. Trzeba zatem, po pierwsze, ustalić stan ilościowy księgozbioru w pewnym określonym czasie, następnie dopiero przeprowadzić szczegółową analizę i charakterystykę jego treści, nie ograniczając się tylko do zwykłego bezkrytycznego wyliczania tytułów, ale skupić się na subtelnym wyodrębnieniu i podkreśleniu najważniejszych i szczególnie charakterystycznych rzeczy ${ }^{14}$.

Realizując wytyczone cele, należy oprzeć się oczywiście na źródłach, rozumianych tutaj, według Kazimiery Maleczyńskiej, jako ślady produkcji książki oraz istnienia i działalności bibliotek ${ }^{15}$. Dobór odpowiednich materiałów źródłowych determinuje pole badawcze historii bibliotek ${ }^{16}$. „Prawidłowość doboru źródeł zależy [...] od zastosowania odpowiedniej klasyfikacji, a raczej typologii źródeł, kładącej nacisk na ich naukową użyteczność i pozwalającej wyodrębnić poszczególne grupy źródeł, ze względu na ich genezę, formę i treść" 17 .

System książki wytworzył z czasem coraz większą liczbę materiałów źródłowych, zachowanych do dzisiaj lub nie. „Przyrastanie tego uniwersum źródeł, ich różnicowanie, doskonalenie formalne i merytoryczne dokumentów, które mówią o przeszłości książki, mogą stanowić przedmiot badań warunkujących w niemałym stopniu i poprzedzających faktograficzne

${ }_{12}$ M. Juda, Bibliologia historyczna..., s. 18; taż, Bibliologia historyczna: między tradycją a nowymi perspektywami [w:] Bibliologia i informatologia, pod red. D. Kuźminy, Warszawa 2011, s. 28.

13 A. Świerk, Średniowieczna biblioteka..., s. 7.

${ }^{14}$ Tamże, s. 7-8.

${ }^{15}$ K. Maleczyńska, Źródła do dziejów ksią̇ki i bibliotek okresu renesansu, „SK” 1986, t. 16, s. 20; K. Migoń, Bibliologia wśród innych nauk..., s. 21; za najlepsze określenie źródła historycznego należy uznać definicję Jerzego Topolskiego, który uważa za nie wszelkie źródła poznania historycznego (bezpośredniego i pośredniego), tzn. wszelkie informacje o przeszłości społecznej, gdziekolwiek one są, razem z tym, co owe informacje przekazuje, czyli kanałem informacyjnym (K. Maleczyńska, Źródła do dziejów..., s. 20; J. Topolski, Metodologia historii, Warszawa 1973, s. 344; J. Szymański, Nauki pomocnicze historii, wyd. VI, Warszawa 2008, s. 28.).

${ }^{16}$ J. Puchalski, Propozycja typologii źródeł do historii bibliotek $w$ Polsce $w$ latach 1918-1947, [w:] Bibliologia. Problemy badawcze, s. 298.

17 Tamże, s. 298. 
studia w zakresie historycznego księgoznawstwa" ${ }^{18}$. Należy także wiedzieć, jak źródła te były wykorzystywane, jaką przypisywano im rangę w różnych okresach, czyli jak kształtowało się pojęcie źródła bibliologicznego i jak powstawał i funkcjonował warsztat badawczy historyka książki ${ }^{19}$.

Przyjmując metodologię Jerzego Topolskiego, źródła należy podzielić na bezpośrednie i pośrednie oraz na pisane i niepisane ${ }^{20}$. Dla badań bibliologicznych najważniejsza jest ta ostatnia klasyfikacja, przy czym do źródeł pisanych należy zaliczyć dokumenty graficzne, zaś do niepisanych zabytki materialne ${ }^{21}$. Krzysztof Migoń wyróżnia ponadto jeszcze jedną osobną grupę źródeł - epigraficzne, które znajdują się na pograniczu źródeł pisanych i materialnych ${ }^{22}$.

Źródła pisane dzielą się na archiwalne i noszące charakter biblioteczny ${ }^{23}$. Do źródeł pisanych archiwalnych zaliczają się m.in. dokumenty i księgi prowadzone przez urzędy, w których odnotowywano przede wszystkim czynności o charakterze prawnym - są to źródła archiwalne urzędowe. Do tych dokumentów należą w pierwszym rzędzie księgi miejskie: radzieckie, wójtowskie, ławnicze, księgi sądów kryminalnych, księgi rachunków miejskich, testamenty. Mieszczanie byli producentami książek i zajmowali się ich sprzedażą. Przy okazji informacji o zmianie właściciela budynku lub o sprawie sądowej można dowiedzieć się o istnieniu oficyn drukarskich i papierni2 ${ }^{24}$.

Do tego typu źródeł zaliczają się także spisy ruchomości sporządzone po śmierci osób zmarłych na terenie miast. Spisy zawierają wykazy ksiąg, jednak bez pełnych danych bibliograficznych, czasem określają sumarycznie całe grupy druków. Stanowią one dobre źródło informacji o księgozbiorach mieszczańskich i szlachty, która miała swoje domy w miastach. Należy tutaj zaliczyć również inwentarze księgarń i warsztatów introligatorskich ${ }^{25}$.

Do źródeł archiwalnych należy zaliczyć również Metrykę Koronną, gdzie znajdują się wpisy o drukarniach, papierniach, o cenie budynku, jego rozmiarach, konstrukcji, nazwisku i pochodzeniu właściciela, liczbie pracowników, przywilejach dla drukarzy ${ }^{26}$.

\footnotetext{
${ }^{18}$ K. Migoń, Problematyka źródłoznawcza w bibliologii, „SK” 1985, t. 15, s. 7.

19 Tamże, s. 7.

20 J. Topolski, Metodologia historii, s. 348; J. Szymański, Nauki pomocnicze..., s. 28-29.

${ }^{21}$ K. Maleczyńska, Źródła do dziejów..., s. 20-21; K. Migoń, Problematyka źródłoznawcza $w$ bibliologii, s. 5 .

22 Tamże.

${ }^{23}$ K. Maleczyńska, Źródła do dziejów..., s. 21.

24 Tamże.

25 Tamże.

${ }^{26}$ Tamże; A. Żbikowska-Migoń, Wydawnictwa źródłowe do dziejów ksiażki w Polsce. Stan i potrzeby, „SK” 1985, t. 15, s. 41.
} 
Źródłami archiwalnymi urzędowymi są także akta notarialne i hipoteczne. Mają one duże znaczenie w badaniach nad historią książki i czytelnictwa w XIX-XX wieku (instytucja notariatu na ziemiach polskich powstała w 1808 roku w Księstwie Warszawskim, a akta hipoteczne zaprowadzono po 1825 roku), a zwłaszcza w poszukiwaniach biograficznych. Akta notarialne to protokoły wszelkiego typu umów niespornych, aktów dobrej woli, czyli umowy kupna-sprzedaży, umowy dzierżawy, najmu, darowizny, plenipotencje, cesje, umowy pożyczki, protesty weksli, inwentarze majątku, licytacje, działy majątku, odpisy aktów z innych kancelarii, upoważnienia, zaświadczenia, plany, rejestry, wycinki z prasy zawierające ogłoszenia o licytacji. Z kolei akta hipoteczne obejmują wykaz hipoteczny i zbiór dokumentów do każdej z transakcji czy umów się odnoszących. Księgi hipoteczne (księgi wieczyste) tworzą wykazy hipoteczne z danymi o właścicielu i nieruchomości, księgi umów wieczystych odnoszących się do danej nieruchomości, zbiór dokumentów (dowody własności i inne) niezbędnych dla uwierzytelnienia transakcji ${ }^{27}$.

Spośród tych rodzajów dokumentów największe zainteresowanie bibliologów budzą akta związane z postępowaniem spadkowym, a zwłaszcza inwentarze pozostałości ziemiaństwa, kupców, lekarzy, aptekarzy, geometrów, urzędników, prawników, duchownych, nauczycieli, rzemieślników, przekupek, służby domowej oraz protokoły licytacji, testamenty. W inwentarzach wyliczano książki zmarłej osoby; niestety spisy i wykazy zbiorów bibliotecznych w tych aktach są zwykle bardzo niedokładne (z reguły tutaj posługiwano się tytułem, czasami skróconym, podaniem liczby tomów i wyceną, a po 1830 roku podawano także nazwisko autora, a nawet miejsce i rok wydania) i przez to wymagają pracochłonnych poszukiwań dla ustalenia, o jaką pozycję chodzi. Protokoły licytacji uzupełniają wiedzę o dalszych losach księgozbiorów, przedstawiając spis rzeczy poddanych sprzedaży: zwierają informacje o nabywcach książek, cenie kupna, zapiski o ewentualnym podziale księgozbioru, tytułach wyłączonych z licytacji przez cenzurę. W testamentach natomiast zawarte były wiadomości o przekazaniu książek do bibliotek kościelnych przez księży, dyspozycjach dotyczących większych księgozbiorów lub przeznaczenia książek fachowych: książki były jednak rzadko przedmiotem oddzielnej dyspozycji testamentowej ${ }^{28}$.

${ }^{27}$ H. Chamerska, Akta hipoteczne i notarialne jako źródła badań nad ksieggozbiorami prywatnymi XIX-XX wieku (zagadnienia metodologiczne), „Z Badań nad Polskimi Księgozbiorami Historycznymi” (dalej: „BPKH”) 1977, z. 3, s. 7, 14; A. Dymmel, Akta notarialne w warsztacie badań bibliologicznych [w:] Bibliologia. Problemy badawcze..., s. 52.

${ }^{28}$ H. Chamerska, Akta hipoteczne..., s. 14, 16-18; A. Dymmel, Akta notarialne..., s. 53-59. 
Do niezwykle ważnych źródeł archiwalnych należą inwentarze (katalogi) biblioteczne klasztorów, kościołów, bibliotek szlachecko-magnackich, miejskich, uniwersyteckich, szkolnych, towarzystw czytelniczych, zbiorów prywatnych łącznie $\mathrm{z}$ inwentarzami pośmiertnymi, pozbawione innych, poza księgami, spisów ruchomości. Katalogi te są fundamentem wielorakich poczynań badawczych i jednym z pierwszoplanowych obiektów studiów. Są one (inwentarze) podstawowym źródłem do historii bibliotek, wyraźnie wyodrębnionej części historycznego księgoznawstwa. Służą również historii czytelnictwa, dostarczają informacje o innych aspektach kultury książki ${ }^{29}$.

Opisy bibliograficzne $\mathrm{w}$ inwentarzach bibliotek klasztornych pomijają całkowicie adresy wydawnicze druków, często podają tylko nazwisko autora, bez jego imienia lub samo imię bez nazwiska, bądź też jego imię i nazwisko bez tytułu książki, albo sam tytuł - zawsze skrócony - bez autora. Czasami wymieniony jest tylko pseudonim pisarza. W takich wypadkach należy zastosować metodę bibliograficzną polegającą najpierw na dekompozycji spisu na poszczególne jednostkowe opisy bibliograficzne (przydaje się przy tym znajomość paleografii dla dawnych spisów i neografii dla nowszych spisów), a następnie próbie rozpoznania, opisywania i opracowania repertuaru piśmienniczego ${ }^{30}$. Inwentarze bibliotek klasztornych powinno traktować się jako wyraz stosunku poszczególnych zakonów (klasztorów) do książki, ponieważ na ich podstawie można określić kulturę książki w poszczególnych klasztorach, stopień dbałości przeorów o utrzymanie biblioteki, a zatem także poziom umysłowy zakonników ${ }^{31}$.

Ważne są też księgi celne i spisy podatkowe, generalnie wszelkiego rodzaju rachunki, przede wszystkim dworów królewskich i uczelni wyższych, z których dowiadujemy się o wydatkach na książki, o darach pieniężnych, o kosztach związanych z urządzeniem i utrzymaniem lokalu biblioteki w należytym stanie ${ }^{32}$.

${ }^{29}$ K. Migoń, Dawne katalogi biblioteczne jako źródło wiedzy o kulturze książki, „Roczniki Biblioteczne" 2005, R. 49, s. 301.

${ }^{30}$ K. Bednarska-Ruszajowa, Metoda bibliograficzna i jej zastosowanie [w:] Z problemów metodologii i dydaktyki bibliotekoznawstwa i informacji naukowej, „Zeszyty Naukowe Uniwersytetu Jagiellońskiego. Prace Historycznoliterackie”, 1989, z. 74, s. 39, 42; J. Gwioździk, Historyczne kolekcje..., s. 169-170; T. Stolarczyk, Biblioteka łęczyckiego konwentu dominikańskiego i jej księgozbiór w początkach XVII wieku [w:] Przestrzeń informacyjna ksiązki, pod. red. J. Koniecznej, S. Kurek-Kokocińskiej, H. Tadeusiewicz, Łódź 2009, s. 236; tenże, Biblioteki klasztorne Braci Kaznodziejów w Gidlach, Łęczycy, Łowiczu, Piotrkowie Trybunalskim i w Sieradzu i ich księgozbiory w XVII wieku, „Acta Universitatis Lodziensis. Folia Librorum” 2010, nr 16, s. 50-52.

${ }^{31} \mathrm{~K}$. Warda, Inwentarze bibliotek klasztornych jako źródło do dziejów książki polskiej w XIX w., SK 1985, t. 15, s. 120.

32 K. Maleczyńska, Źródła do dziejów..., s. 23. 
Interesujące są edykty królewskie poruszające sprawy książki w związku $\mathrm{z}$ różnymi formami cenzury. Użyteczne są również akta kapituł kościelnych zawierające informacje o zakazie czytania niektórych dzieł, bulle papieskie, kolejne wersje Indeksu ksiąg zakazanych, akta konsystorza biskupiego, akta wizytacji kościelnych, opisujące dokładnie biblioteki parafialne i kolegiac$\mathrm{kie}^{33}$.

Do źródeł pisanych niearchiwalnych należy zaliczyć przede wszystkim inwentarze bibliotek prywatnych, a także korespondencję, która pomimo dobrej opinii źródła bogatego w informacje na temat książek, ma pewne mankamenty, zwłaszcza ta renesansowa: list odrodzeniowy tworzony był w ramach pewnej konwencji, dlatego informacje i sądy często się powtarzają. Dużo jest też zwrotów o charakterze moralizatorskim. Dlatego też trudno znaleźć w ówczesnych listach rzetelne informacje o książce ${ }^{34}$. Inaczej jest już w przypadku korespondencji dziewiętnastowiecznej, która, podobnie jak dziewiętnastowieczne pamiętniki, dostarcza cennych informacji na temat współpracy księgarzy z innymi księgarzami, wydawcami czy drukarzami, autorami, rejestruje i komentuje różne fakty, składające się na „życie książki”"

Bardzo ważne źródło do dziejów dawnych bibliotek i księgozbiorów stanowią instrukcje biblioteczne redagowane przez zakony, a także ich reguły, konstytucje, statuty, których odbiciem są, według Kazimierza Wardy, zasoby biblioteczne ${ }^{36}$.

Istotne są też wypowiedzi szesnastowiecznych pisarzy na temat książek. Mają one charakter raczej postulatywny i są cennym świadectwem opinii społecznej na ten temat, ale nie dostarczają rzetelnej informacji o dziejach książki i bibliotek. Przydatne są opisy podróży, a także utwory pisane i drukowane w związku ze śmiercią wybitnych osobistości ${ }^{37}$.

Piśmiennictwo księgoznawcze XIX wieku jest dość obfite i różnorodne. Jest ono świadectwem kształtowania się nowej dyscypliny naukowej oraz zawiera konkretny materiał informacyjny. Zdaniem Marianny Mlekickiej „[...] wszelkie opracowania o drukarstwie czy księgarstwie dziewiętnastowiecznym opublikowane w XIX i na początku XX wieku przedstawiają

${ }_{33}$ Tamże, s. 23; B. Bieńkowska, Kilka uwag..., s. 9.

${ }^{34}$ K. Maleczyńska, Źródła do dziejów..., s. 23-24.

${ }^{35}$ M. Mlekicka, Wykorzystanie źródeł drukowanych z lat 1795-1918 do badań nad dziejami ksiązki polskiej (zarys metodologiczny), „BPKH” 1977, z. 3, s. 50-51.

${ }_{36}$ Tamże, s. 24; K. Warda, Inwentarze bibliotek..., s. 121.

${ }^{37}$ K. Maleczyńska, Źródła do dziejów..., s. 24-25; K. Migoń, Problematyka źródłoznawcza $w$ bibliologii, s. 7-8. 
obecnie wartość tylko ze względu na zawarty w nich materiał informacyjny, gdyż ich autorzy nie mieli właściwej perspektywy historycznej dla oceny zaszłych przemian" ${ }^{38}$. Wartość informacyjną posiadają również rejestry wypożyczeń, luźne notatki odnoszące się do kupna, darowizn, dziedziczenia, zastawów, sprzedaży i wypożyczania poszczególnych egzemplarzy. Podobnie należy traktować relacje średniowiecznych kronikarzy lub pisarzy oraz wiadomości zawarte w legendach o świętych i wiadomości o działalności skryptoriów lub poszczególnych pisarzy ${ }^{39}$.

Ważnym materiałem źródłowym w badaniach księgoznawczych są ogłoszenia, które w polskiej prasie pojawiły się jako forma reklamy książki w pierwszej połowie XVIII wieku. Ogłoszenia występują w dziennikach (najliczniej), tygodnikach, miesięcznikach, rzadziej ukazujących się periodykach o charakterze naukowym, społeczno-kulturalnym i literackim oraz w kalendarzach, wydawnictwach o charakterze informacyjnym, do których zaliczają się przewodniki turystyczne, księgi adresowe, informatory handlowe, przemysłowe itp. Ogłoszenia pojawiają się także w postaci luźnych kartek: cyrkularze, prospekty. Najczęściej ogłoszenia pochodzą od firm księgarsko-nakładowych, drukarskich, litograficznych, giserskich, introligatorskich, wydawców i redaktorów czasopism, większych dzieł wydawanych nieprofesjonalnie, od autorów i innych osób ${ }^{40}$.

Pod względem treści ogłoszenia można podzielić na 3 grupy: odzwierciedlające dzieje poszczególnych firm, ukazujące rodzaj prowadzonej działalności i dotyczące konkretnych pozycji wydawniczych. Najliczniejsza grupę stanowią ogłoszenia reklamujące różne typy wydawnictw, jak książki polskie i obce, czasopisma, ryciny, nuty i mapy. Wśród ogłoszeń można wyodrębnić zapowiedzi wydawnicze, poprzedzające ukazanie się dzieła, informacje o nowościach wydawniczych już znajdujących się w handlu księgarskim oraz informacje o książkach, które ukazały się wcześniej, a ciągle jeszcze były w sprzedaży. Występują również ogłoszenia o licytacjach prywatnych księgozbiorów bibliotecznych, przeważnie po zmarłych właścicielach, o sprzedaży książek na jarmarkach, z dokładnym wskazaniem kiedy, gdzie i kto będzie sprzedawat ${ }^{41}$.

Podstawowym źródłem informacji o drukach znajdujących się w XIX wieku w obiegu handlowym są również katalogi księgarskie, czyli spisy książek polskich i obcych, czasopism, nut, rycin, map przeznaczonych do sprzedaży

\footnotetext{
${ }^{38}$ M. Mlekicka, Wykorzystanie źródeł..., s. 49-50.

39 A. Świerk, Średniowieczna biblioteka..., s. 7; J. Gwioździk, Historyczne kolekcje..., s. 170.

${ }^{40}$ M. Mlekicka, Wykorzystanie źródeł..., s. 26-28.

${ }^{41}$ Tamże, s. 28-29.
} 
w określonych księgarniach. Katalogi te można podzielić na sortymentowe, czyli zawierające wykaz wydawnictw różnych nakładców, nabytych przez księgarza za gotówkę od firm wydawniczych lub innych księgarskich w celu ich dalszej rozprzedaży; nakładowe (wydawnicze), czyli podające spis druków ogłoszonych nakładem własnym danej księgarni nakładowej (wydawniczej), rozprzedawanych przez tę księgarnię, a także oddawanych do sprzedaży innym księgarniom; komisowe, czyli zawierające wykaz wydawnictw przyjętych przez księgarza w komis oraz na katalogi mieszane księgarzy-wydawców. Istnieją również katalogi sezonowe: podręczników szkolnych, katalogi gwiazdkowe, ogłaszane w określonych porach roku, katalogi podające spis wydawnictw z punktu widzenia ich czytelniczego przeznaczenia: dla dzieci i młodzieży, „dla ludu”, katalogi antykwaryczne, katalogi aukcyjne ${ }^{42}$.

Bogaty materiał źródłowy do dziejów książki, bibliotek i czytelnictwa zawierają także czasopisma, bez względu na swój charakter, przeznaczenie czytelnicze i częstotliwość. Są to czasopisma ogólnonaukowe, kulturalne, społeczno-polityczne, literackie, specjalne poświęcone sprawom książki ${ }^{43}$.

Cennym źródłem do księgoznawstwa są także dziewiętnastowieczne oraz pochodzące z pierwszej połowy XX wieku polskie kalendarze, stanowiące dokument tamtej epoki, odzwierciedlające życie społeczne i kulturalne Polaków, stanowiące czasami jedyne źródło wiadomości odnoszących się do tych dziedzin życia. Wydawcami kalendarzy były firmy drukarskie, księgarskie, wydawnicze, redakcje czasopism oraz różne organizacje i stowarzyszenia świeckie i religijne. Pod koniec XIX wieku coraz częściej ukazywały się kalendarze specjalne przeznaczone dla określonych grup zawodowych: księgarzy, drukarzy. W kalendarzach historycy książki mogą znaleźć wiadomości o zakładach wytwarzających i rozpowszechniających druki, o osobach związanych zawodowo z książką, o piśmiennictwie, drogach kolporta$\dot{z} u$, formach upowszechnianiach czytelnictwa, księgozbiorach ${ }^{44}$.

Obfitym materiałem źródłowym są także wszelkiego rodzaju informatory przeznaczone do bieżącego użytku, wydawane okresowo i ciągle aktualizowane: przewodniki turystyczne po dużych miastach, książki informacyjno-adresowe ogólne (spisy urzędów, instytucji, firm, osób, ulic, domów itp.), informatory gospodarcze, obejmujące handel, przemysł i rzemiosło oraz zestawienia statystyczne: liczbowe zestawienia drukarzy, litografów, giserów,

42 Tamże, s. 30-31.

43 Tamże, s. 33.

44 Tamże, s. 41-44; o polskich kalendarzach z XIX w. pisała I. Turowska-Bar, Polskie kalendarze XIX wieku (streszczenie), Łódź 1967; E. Wójcik, Kalendarze dwudziestolecia międzywojennego (dzieje, problemy literatury i kultury, bibliografia), Kraków 2000, s. 22-25, 41, 66. 
introligatorów, księgarzy, zakładów przemysłowo-handlowych związanych z książką, zatrudnionych w nich pracowników itp. ${ }^{45}$.

Materiały niearchiwalne, zdaniem K. Maleczyńskiej, „cechuje znacznie mniejszy stopień wiarygodności, niż dokumenty i księgi urzędowe. Przy korzystaniu z nich konieczna jest wnikliwa krytyka źródła"46.

Z kolei samą książkę, zarówno tę drukowaną, jak i kodeks średniowieczny, także należy traktować jako bardzo ważne źródło pisane i materialne, dla badań bibliologicznych ${ }^{47}$. Inkunabuły i starodruki rozumiane jako narracja historyczna stworzona przez minione pokolenie dziejopisów to także źródła historyczne ${ }^{48}$. „Wnikając w jej treść [książki - TS] badać możemy strukturę treściową repertuaru wydawniczego i księgozbiorów. [...] Repertuar wydawniczy, jeżeli analizować go w skali odpowiednio wielkiego terytorium, decyduje o strukturze treściowej bibliotek i czytelnictwie"49.

Szczególną grupę książek stanowią łatwo ulegające zniszczeniu lub zagubieniu, określane często jako „zaczytane”, o użytkowaniu, których nie można wnioskować $\mathrm{z}$ wymieniania ich $\mathrm{w}$ spisach księgozbiorów, ale $\mathrm{z}$ ich występowania $\mathrm{w}$ repertuarze wydawniczym. Do tej grupy zaliczyć należy książki o małych formatach, druki związane z gospodarstwem domowym, dzieła pseudonaukowe jak almanachy czy prognostyki, publikacje techniczne, księgi medyczne, książki szkolne, literatura popularna w języku narodowym, książki do nabożeństwa, książki używane przez kupców, publikacje skierowane przeciw władzy świeckiej lub duchownej ${ }^{50}$.

Istotne okazują się również listy dedykacyjne w książkach, stanowiące przede wszystkim źródło do badań nad dziejami mecenatu ${ }^{51}$.

Do źródeł pisanych zaliczyć należy także znaki stawiane przez czytelnika: uwagi słowne, podkreślenia fragmentów książek; niektóre znaki własnościowe: podpisy na książkach wzbogacone o informacje na temat przynależności społecznej, zawodu właściciela, jego pochodzenia, daty i sposobie nabycia książki. Elementy słowne zawierają także ekslibrisy i superekslibrisy ${ }^{52}$.

${ }^{45}$ M. Mlekicka, Wykorzystanie źródeł..., s. 44-47.

${ }^{46}$ K. Maleczyńska, Źródła do dziejów..., s. 25.

${ }^{47}$ Tamże, s. 21, 25; K. Migoń, Problematyka źródłoznawcza w bibliologii, s. 6; M. Juda, Bibliologia historyczna w systemie nauk pomocniczych historii, s. 16.

${ }_{48}$ R. Gaziński, Materiały archiwalne, materiały biblioteczne a warsztat pracy historyka [w:] Bibliologia. Problemy badawcze, s. 313; M. Juda, Inkunabuł jako źródło historyczne [w:] Tekst źródła. Krytyka. Interpretacja, pod red. B. Trelińskiej, Warszawa 2005, s. 179-186.

${ }^{49}$ K. Maleczyńska, Źródła do dziejów..., s. 25.

50 Tamże, s. 25-26.

51 Tamże, s. 26.

52 Tamże, s. 26-27. 
Znaki własnościowe, które nadają egzemplarzowi cechy ściśle indywidualne, wyróżniające go z szeregu innych, identycznych pod względem wydawniczym, a czasem sam typ oprawy pozwalają na odtworzenie biblioteki, z której dana książka pochodzi, a także stanowią źródło do badania wędrówek książek. Służą temu badania proweniencyjne, o których szczegółowo pisała Maria Sipayłło ${ }^{53}$. Wówczas przydaje się warsztat historyka. Szczególnie jest on pomocny przy rozszyfrowaniu superekslibrisu, na który składają się czasami jedynie inicjały właściciela i jego herb, który w polskim systemie heraldycznym, opartym na ustroju rodowym, używany jest przez wiele rodzin noszących zupełnie różne nazwiska. Potrzebna tu zatem jest znajomość heraldyki. Inicjały da się rozszyfrować jedynie w przypadku osób, które odegrały jakąś rolę historyczną. Przydatna również jest toponomastyka, która niezbędna jest przy prawidłowym tworzeniu nazwisk, nie tylko szlacheckich, typu przymiotnikowego od nazw miejscowości, tym bardziej, że polskie herbarze nie zawierają wszystkich nazwisk szlachty. Do prawidłowego odczytania zapisków proweniencyjnych na inkunabułach i starodrukach potrzebna jest też doskonała znajomość paleografii, która należy do nauk pomocniczych historii. Niezbędna jest również znajomość zasad latynizacji nazwisk, która przydaje się także $\mathrm{w}$ badaniach stricte historycznych ${ }^{54}$.

Książka jako przedmiot kultury materialnej również jest wartościowym i wieloaspektowym źródłem. Sam materiał piśmienniczy dostarcza ważnych informacji o książce. Pergamin może być badany pod kątem jego gatunku, pochodzenia i walorów estetycznych. Ustalenie miejsca i czasu wyprodukowania papieru pomaga potwierdzić lub uściślić czas powstania książki, jej walory estetyczne oraz drogi handlu papierem ${ }^{55}$.

Zewnętrzna strona tekstu także jest ważnym źródłem informacji. Poddana badaniom typograficznym ujawnia warsztat drukarski, z którego wyszedł dany druk, jeżeli nie ma w tekście i w kolofonach żadnych danych wyjaśniających ten problem ${ }^{56}$.

Również elementy zdobnicze - malarstwo książkowe, drzeworyt a nawet miedzioryt - to także istotne źródło o dawnej książce w powiązaniu z taką czy inną szkołą $a^{57}$.

${ }_{53}$ Tamże, s. 27; B. Bieńkowska, Kilka uwag..., s. 9; M. Sipayłło, O metodzie badań proweniencyjnych starych druków, „BPKH” 1975, z. 1, s. 9-30.

${ }_{54}$ M. Sipayłło, O metodzie badań...., s. 11-13; M. Juda, Bibliologia historyczna: między tradycją a nowymi perspektywami, s. 28; taż, Bibliologia historyczna w systemie nauk pomocniczych historii, s. 18.

${ }_{55}$ K. Maleczyńska, Źródła do dziejów..., s. 27; P. Dymmel, Nauki pomocnicze bibliologii, s. 289.

${ }^{56}$ K. Maleczyńska, tamże, s. 27-28.

57 Tamże, s. 28. 
Duże znaczenie ma też oprawa. Analiza materiału, z jakiego została wykonana: usztywnienia okładki, skóry czy tkaniny, jakimi została powleczona oraz wyklejek, a zwłaszcza zdobnictwa, pozwala na określenie czasu oraz miejsca jej powstania, a nawet niekiedy umożliwia przypisanie książki do danej biblioteki ${ }^{58}$.

Bywa, że istotne mogą okazać się znalezione w książkach ślady konserwacji, przeprawienia, usuwania tekstu ${ }^{59}$.

Zdaniem B. Bieńkowskiej pierwszorzędne znaczenie mają również zachowane pomieszczenia biblioteczne, sprzęty, urządzenia, narzędzia, ikonografia (wyobrażenia malarskie, graficzne, rzeźbiarskie bibliotek, skryptoriów a nawet poszczególnych książek, plany architektoniczne, projekty wystroju lokali bibliotecznych ${ }^{60}$.

Jacek Puchalski wyróżnił dla historii bibliotek w latach 1918-1947 następujące rodzaje źródeł: instytucjonalne - wytworzone przez instytucje nadrzędne w stosunku do bibliotek, wytworzone przez biblioteki, wytwarzane przez instytucje i organizacje związane z bibliotekami relacją równorzędności oraz źródła nieinstytucjonalne - wytwarzane poza bibliotekami i instytucjami nadrzędnymi lub niezależnymi w stosunku do bibliotek. Każdy z tych typów J. Puchalski podzielił na źródła pisane: rękopiśmienne i drukowane źródła aktowe, rękopiśmienne i drukowane źródła opisowe, następnie na źródła pośrednie między pisanymi i niepisanymi oraz źródła niepisane. Podział ten za swoją podstawę przyjmuje wytwórcę źródła ${ }^{61}$.

„Instytucjonalność, oficjalność, formalny charakter znacznej większości źródeł do historii bibliotek wpływa na ocenę ich wiarygodności i użyteczności naukowej"

„Charakter źródeł w badaniach historyczno-bibliologicznych [...] w postępowaniu badawczym wymaga adaptowania na grunt badań bibliologicznych historycznych dyscyplin pomocniczych"63.

Średniowieczny kodeks rękopiśmienny i wczesnonowożytne manuskrypty mogą być odczytane tylko dzięki paleografii. Tekst średniowiecznej książki rękopiśmiennej musi zostać poddany krytyce, aby wykazać, czy dany kodeks zawiera oryginał danej jednostki piśmienniczej, czy też kopię,

\footnotetext{
58 Tamże.

59 Tamże.

60 B. Bieńkowska, Kilka uwag..., s. 10.

61 J. Puchalski, Propozycja typologii..., s. 298-299.

${ }^{62}$ Tamże, s. 299.

63 M. Juda, Bibliologia historyczna w systemie nauk pomocniczych historii, s. 19.
} 
a jeśli tę ostatnią, to jakie jest jej miejsce w filiacji tekstów ${ }^{64}$. Architekturą kodeksu w rozwoju historycznym, jak określa to M. Juda, a zatem badaniem rękopisu całościowo, jego formy, materiału i narzędzi pisarskich, budową, zdobnictwem, treścią i oprawą zajmuje się kodykologia. Kodykolog, oprócz paleografii, korzysta również z prac z zakresu papirologii, filigranistyki, heraldyki, genealogii, chronologii, języka i kultury literackiej, edytorstwa historycznego ${ }^{65}$.

Podobnie rzecz się ma ze źródłami do historii bibliotek i księgozbiorów. Każde źródło musi być poprawnie odczytane oraz poddane analizie krytycznej pomagającej sprawdzić jego wiarygodność, która odnosi się zarówno do informacji, jak i do informatora, który tę informację przekazuje. Celem zbadania wiarygodności jest ustalenie, czy informator mógł znać prawdę w danej dziedzinie, czy świadomie dążył do przekazania prawdziwej informacji oraz dla kogo była ona przeznaczona. Stopień stwierdzonej wiarygodności decyduje o uznaniu źródła za prawdziwe lub nieprawdziwe. Dla oceny źródeł ważna też jest wiedza o stanie kompletności zachowanych materiałów, ponieważ ma to wpływ na końcowe rezultaty badań ${ }^{66}$. Informacje istotne dla badacza także muszą zostać umiejętnie wyselekcjonowane i odpowiednio opracowane zgodnie ze sztuką.

Dla dziejów książki i bibliotek ważną metodą są również badania biograficzne ${ }^{67}$. W bibliologii „aspekt ludzki”, jak go nazywa Bożena Koredczuk, ma szczególne znaczenie, ponieważ tylko tutaj spotkać można zarówno wybitne indywidualności, jak i zwykłych ludzi pracujących „na polu książki i bibliotek”68. W tej dyscyplinie naukowej „[...] dzięki danym biograficznym można w sposób pośredni zrekonstruować przebieg procesu kształtowania się zarówno postaci materialnej książki, dziejów jej obiegu i odbioru w społeczeństwie, jak i nauki o tym nośniku wielu treści”69.

${ }^{64}$ B. Kürbis, O źródłoznawczej interpretacji kodeksu średniowiecznego [w:] Materiały biblioteczne z konferencji organizowanych w latach 1963-1968 przez Biuro Wydawnictw i Bibliotek PAN, Wrocław [i in.] 1971, s. 234.

${ }^{65}$ M. Juda, Bibliologia historyczna w systemie nauk pomocniczych historii, s. 16; taż, Bibliologia historyczna: między tradycją a nowymi perspektywami, s. 26-27.

${ }^{66}$ M. Mlekicka, Wykorzystanie źródeł..., s. 51; M. Juda, Bibliologia historyczna: między tradycja a nowymi perspektywami, s. 26; taż, Bibliologia historyczna w systemie nauk pomocniczych historii, s. 14-15.

${ }^{67}$ J. Gwioździk, Historyczne kolekcje..., s. 173; B. Koredczuk, Biografia jako kategoria badawcza w polskiej bibliologii [w:] Bibliologia. Problemy badawcze, s. 61.

${ }_{68}^{6}$ B. Koredczuk, Biografia jako kategoria..., s. 61.

${ }^{69}$ Tamże, s. 61. 
Biografistyka należy do najstarszych gatunków historiografii. Odtworzenie przebiegu życia jest bowiem pracą historyczną. W metodologii nauk istnieją dwa modele biografii. Pierwszy z nich to model naukowy biografii historycznej. Jest on oparty na bogatej bazie źródłowej, która stara się opisać przebieg życia danej osoby, próbując jednocześnie dociec motywów jej postępowania; wykorzystywany najczęściej w naukach historycznych i bibliologii historycznej. Drugi model to model literacko-estetyczny, w którym interpretacja motywów postępowania bohatera biografii może wybiegać poza te umotywowane w źródłach, a sposób prezentacji przebiegu życia zbliża się do kanonów stosowanych w literaturze pięknej. Historycy w ramach naukowego modelu biografii wyróżniają kilka jej rodzajów. Są to przede wszystkim biografie indywidualne i zbiorowe. Te pierwsze ze względu na sposób ujęcia przebiegu życia dzielą się na: kompletne, o całym życiu jej bohatera, tematyczne, dotyczące określonej dziedziny życia, np. działalności zawodowej, politycznej, społecznej i cząstkowe, omawiające pewien okres z życia osoby będącej jej przedmiotem. Biografie zbiorowe są portretem zbiorowym jakiejś grupy czy środowiska, połączonego więzią ideową, psychiczną, zawodową ${ }^{70}$.

Materiały biograficzne wykorzystywane są często w badaniach nad historią bibliotek i bibliotekarstwa. W badaniach bibliotek prywatnych $\mathrm{z}$ tego typu źródeł można dowiedzieć się o upodobaniach i zainteresowaniach literackich, naukowych, religijnych czy politycznych właściciela biblioteki. Metoda biograficzna jest bardzo przydatna w rekonstrukcji procesów czytelniczych. Badanie różnego rodzaju dedykacji, proweniencji (ekslibrisów, superekslibrisów, innych znaków własnościowych), zapisków dokonanych przez czytelników i właścicieli na książkach pomaga określić gusta literackie i preferencje wyboru konkretnego tekstu, kształtowanie się różnych poglądów. W badaniach nad bibliofilstwem dzięki dokumentom biograficznym, a zwłaszcza autobiograficznym, można przeanalizować atmosferę domu rodzinnego i jej wpływ na zainteresowanie książkami ${ }^{71}$.

Każda biblioteka i każdy księgozbiór istniały w określonym czasie i środowisku. Analiza tych elementów i powiązań bibliotek i księgozbiorów z nimi to także zadania historyków-bibliologów. Do nich należy również zakreślenie topografii bibliotek, różnych rodzajów, w aspekcie synchronicznym (przestrzeń w momencie historycznym) i diachronicznym (przestrzeń $\mathrm{w}$ procesie historycznym $)^{72}$.

70 Tamże, s. 64-65; A. Gruca, Metoda biograficzna w badaniach nad dziejami książki okresu zaborów [w:] Bibliologia. Problemy badawcze, s. 72.

${ }^{71}$ B. Koredczuk, Biografia jako kategoria..., s. 66.

${ }^{72}$ J. Gwioździk, Historyczne kolekcje...., s. 168. 
„Materiały biblioteczne są traktowane przez historyków na równi z pełnowartościowymi źródłami. Można więc postawić znak równości między materiałami bibliotecznymi a archiwalnymi"73.

Należy zgodzić się z Jolantą Gwioździk, że tak naprawdę historyk nie odtwarza przeszłości, ale tworzy jedynie pewien jej obraz, zgodny oczywiście z zachowanymi źródłami, lecz subiektywnie oceniany (np. ze względu na wiarygodność źródeł, indywidualnie ocenianą ich użyteczność, a nawet przyjętą ideologię) $)^{74}$. Oto historia i historyk w bibliologii.

\begin{abstract}
History in "bibliology". The role of historical researches in reconstruction of history of libraries and collections of books

"Bibliology" is a study about book, covering among others also librarianship which has libraries as main subject of research together with their history. To some extent "bibliology" and librarianship caver common area - in other words they are complementary. History equips bibliological research with some tools. I intent to present the most important of them in hereby article, as well as describe their essence, the way of use and importance for the "bibliology".
\end{abstract}

${ }^{73}$ R. Gaziński, Materiały archiwalne..., s. 314.

${ }^{74}$ J. Gwioździk, Historyczne kolekcje...., s. 168. 